\title{
NON-AGENDA
}

With the view of causing an increase to take place in the mass of national wealth, or with a view to increase of the means either of subsistence or enjoyment, without some special reason, the general rule is, that nothing ought to be done or attempted by government. The motto, or watchword of government, on these occasions, ought to be - Be quiet. . . Whatever measures, therefore, cannot be justified as exceptions to that rule, may be considered as non-agenda on the part of government.

\section{The DIFF: An Obituary}

\section{Ross H. McLeod and Sandy Cuthbertson}

\begin{abstract}
A USTRALIa has world-standard performers in the art of protecting special public-spending programs. Even so, the uproar that followed the recent decision to drop the Development Import Finance Facility (DIFF) was striking. Strong press comment ('dumb, dumb, dumb', cried Greg Sheridan in The Australian of 10 June), complaints from ambassadors and government ministers from aid-receiving countries, questions in Parliament, and a Senate inquiry, all suggested that the DIFF meant a lot to many people. And since its inauguration in 1980, systems and procedures for feasibility studies, monitoring and ex post evaluation had been developed by AusAID (Australia's foreign aid agency) in an effort to ensure that DIFF projects were economically and socially useful.

Does all the agonising mean that the government erred in dismantling an effective part of the aid program, which had the support of both donors and recipients? Or does it signify that the scheme was a source of considerable benefits to particular Australian groups, removal of which was bound to be accompanied by squeals?
\end{abstract}

\section{Political and Economic Issues}

There are actually two separate issues bound up in the DIFF controversy. The first is political, and concerns whether it was good policy for the federal government,

Ross McLeod is an economist in the Research School of Pacific and Asian Studies at The Australian National University. Sandy Cuthbertson is Managing Director of the Centre for International Economics (Canberra and Sydney). 
having decided to terminate this form of aid, to abort projects already approved in principle. A more considered exit from the scheme might have saved some aggravation and the embarrassment of having to reinstate some projects. Yet termination of the DIFF had been Liberal-National Coalition policy for some years before it came to office; and there is much to be said for 'chopping off the dog's tail in one strike'. Both sides in this debate can advance reasonable arguments.

The second issue is economic, and has been largely ignored. Given that taxpayers were prepared (or at least required) to contribute some of their own income to the aid budget in the expectation that it would benefit people in developing countries, the government's responsibility was presumably to maximise that benefit for a given taxpayer outlay. If the DIFF was inferior in this respect to other forms in which aid could be delivered, the government probably did the right thing by taxpayers in abolishing it. This is the issue we explore here.

\section{The Scheme Outlined}

What was the DIFF? Its objectives, as articulated by AusAID, were twofold: to effectively deliver development benefits to recipient countries; and to bring substantial commercial benefits to Australia. By the time the scheme was terminated, it was consuming some $A \$ 120 \mathrm{~m}$, or about 10 per cent, of Australia's total aid budget.

The joint Department of Foreign Affairs and Trade (DFAT) and AusAID submission to the August 1996 Senate Inquiry provided an example which showed how DIFF worked (DFAT-AusAID, 1996:1), which may be summarised as follows. In the Luoyang Coal Gasification Plant (China), AusAID provided an aid grant of $\$ 2.6 \mathrm{~m}$ (being 35 per cent of the eligible contract value) and the Australian Export Finance and Insurance Corporation (EFIC) provided an export credit of $\$ 4.8 \mathrm{~m}$ (making up the remaining 65 per cent). These were combined to provide a loan of $\$ 7.4 \mathrm{~m}$ to the plant company to pay the contractor - an Australian construction company. The loan had a grace period of two years, a five-year repayment period, and an interest rate of zero per cent.

This example illustrates the two essential characteristics of the DIFF. First, it was tied to Australian firms: only Australian companies could bid to undertake the projects involved. This is the means by which it was ensured that there were commercial benefits to Australia (although this is a characteristic of most of Australia's aid; and most other countries follow the same practice). Second, it provided concessional finance to developing country governments by mixing an AusAID grant (contributed by taxpayers) with an EFIC loan at a market interest rate.

In this example, the cash flow from repayment of the $\$ 7.4 \mathrm{~m}$ loan by the Chinese government at zero interest just enabled EFIC to repay its own $\$ 4.8 \mathrm{~m}$ borrowing at the market rate. But if, instead, the Chinese government had been required to repay a loan of $\$ 4.8 \mathrm{~m}$ (65 per cent of the project cost) at the full market rate, the repayments would have been identical. The DIFF financial arrangements were, therefore, the equivalent of simply selling the Gasification Plant to China at a discount of 35 per cent to the Australian supply price. 
This is the clearest way to think about the DIFF for analytical purposes. It aimed to provide recipient governments with aid in the form of long-term investments (steel bridges were one of the most common projects), supplied by Australian companies, at a discount of 35 per cent to their purchase price. Australian firms certainly benefited commercially, since they obviously would have found it much easier to sell overseas when their effective price was lowered by 35 per cent. And, on the face of it, the development benefits also seem clear enough (assuming the projects were well chosen), since the recipient received a valuable piece of infrastructure at a 35 per cent discount. However, we have more to say on both these aspects below.

\section{Arguments For and Against the DIFF}

Arguments about the merits and failings of the DIFF became well worn during its lifetime. Proponents saw DIFF projects as ideal for achieving AusAID goals namely, to deliver both development benefits and commercial benefits - and were genuinely mystified by any criticism of the scheme. In particular, Australian companies which supported the DIFF argued that 'everybody was doing it', and that they would have no chance of competing in developing country markets if the Australian govermment did not match the subsidies given by other countries to their own exporters (Peck, 1993:79). Yet many Australian exporters compete on 'spoiled' markets. Grain producers, for example, sell on markets which are to some extent spoiled by the support policies of the United States and the European Union. In such cases, Australian governments have prudently taken the view that this subsidised world must be taken as given, and that it is simply not practical to offset the support of other nations for their exporters.

One frequent criticism was that the DIFF involved investment projects such as bridges, boats, water and electricity supply rather than poverty-focused aid (Rollason, 1993:8-9). But a bridge that connects a previously isolated village to the road network could make villagers better off by cutting transport costs on the goods they buy from, and sell to, the outside world; boats may provide new employment opportunities for fishermen; water storage, treatment and reticulation may have a significant impact on the health of poor communities previously reliant on untreated water from wells and streams; and the supply of electricity and communication facilities to rural areas could make possible all kinds of new, welfare enhancing, productive and leisure activities. And, regardless of the kinds of projects that were most often implemented under the DIFF, they could easily have involved such undertakings as health clinics and environmental enhancement activities. There was no reason, therefore, why DIFF projects, in what they set out to do, should have been inherently better or worse than other AusAID programs.

\section{Efficiency of Aid Delivery}

The key issue is whether the DIFF was more efficient than other possible aid delivery mechanisms. We maintain that a conflict existed between the development 
benefits objective and the commercial benefits objective: the value of aid to recipients was diminished by using the aid budget to assist Australian firms. Suppliers of education (the universities), 'humanitarian' aid (NGOs), and food aid (the Australian Wheat Board and the NSW Ricegrowers' Cooperative), project contractors (construction and manufacturing firms), providers of consultancy services and even government business units (such as water supply utilities) all stand to benefit from being preferred suppliers for taxpayer-funded projects. Since AusAID is a potentially significant buyer of their products and services, the benefits of aid may go to these Australian suppliers and not to the intended aid recipients if the aid mechanism is poorly designed.

A simple example will illustrate the nature of this concern. Suppose that the selling price of bridges purchased from the world's cheapest suppliers happens to be 35 per cent below the price of Australian bridges. This is not an unreasonable assumption because, as noted above, DIFF suppliers have argued that they need the DIFF subsidy in order to be able to compete. Providing Indonesia, say, with an Australian bridge under the DIFF at a discount of 35 per cent would bring no benefit at all to Indonesia, because the discounted price would be the same as the price at which Indonesia could buy an identical bridge, unaided, on the world market. This would be rather like the retailer who marks up his merchandise before having a sale in which everything is available at a discount.

In this extreme case, the Australian taxpayer would contribute 35 per cent of the Australian contractor's supply price without generating any benefit whatsoever for the recipient. This would amount to an export subsidy which, on transparency grounds, should be handled by Austrade, rather than being disguised as aid to poor countries. Whether such a subsidy would be justified is highly dubious. It seems likely that it would be highly concentrated on a small number of firms, and would have the same distortionary effects as providing high rates of effective protection through tariffs.

Suppose Australia wants to give aid in the form of village health clinics. (Ignore, for simplicity's sake, issues relating to the staffing and operation of these clinics.) The government is close to deciding that taxpayers would like it to purchase 100 such clinics on their behalf. But as it is interested in making a more visible impact (McCawley, 1993:14), it is also thinking about purchasing a much larger number of such clinics - 286, to be precise - under the DIFF arrangements. Thus, three possible means of delivering this aid are under consideration.

1. Untied grant. AusAID calls for tenders on the world market for the construction of 100 clinics, to be handed over free to the recipient government.

2. Tied grant. AusAID calls for tenders from Australian firms for the construction of 100 clinics, to be handed over free to the recipient government.

3. DIFF: AusAID calls for tenders from Australian firms for the construction of 286 clinics, to be sold to the recipient government at a discount of 35 per cent. 
The rationale for the DIFF option, as suggested above, is that suppliers of hospital clinics from other countries have access to cheap funding from their own governments, which artificially lowers their effective selling prices: so, in the absence of DIFF, the Australian suppliers' price would be higher than the (subsidised) world price available to the recipient government. Suppose, for example, that the Australian price is $\$ 100,000$ per clinic, while the world price is $\$ 80,000$. To determine the relative efficiency of various means for the delivery of aid, we focus on the ratio of recipient benefit to taxpayer outlay (since we assume that aid should be designed to maximise the recipient benefit for a given taxpayer sacrifice or to minimise the taxpayer sacrifice for a given recipient benefit). Table 1 shows the outcome from the three forms of aid.

\section{Table 1}

\section{Three aid delivery systems: recipient benefits and taxpayer costs}

\begin{tabular}{|l|c|c|c|}
\hline & Untied grant & Tied grant & DIFF \\
\hline Number of clinics & 100 & 100 & 286 \\
\hline Cost to recipient (each) & 0 & 0 & $\begin{array}{r}0.65 \times \$ 100,000 \\
=\$ 65,000\end{array}$ \\
\hline $\begin{array}{l}\text { Net recipient gain per } \\
\text { clinic }\end{array}$ & $\$ 80,000$ & $\begin{array}{c}\$ 80,000 \\
\$ 65,000- \\
\$ 15,000\end{array}$ \\
\hline Total recipient benefit & $\$ 8 \mathrm{~m}$ & $\$ 8 \mathrm{~m}$ & $\begin{array}{c}286 \times \$ 15,000 \\
=\$ 4.3 \mathrm{~m}\end{array}$ \\
\hline Price to taxpayer (each) & $\$ 80,000$ & $\$ 100,000$ & $\begin{array}{c}0.35 \times \$ 100,000 \\
=\$ 35,000\end{array}$ \\
\hline Taxpayer cost & $\$ 8 \mathrm{~m}$ & $\$ 10 \mathrm{~m}$ & $\$ 10 \mathrm{~m}$ \\
\hline Benefit-cost ratio & 1.0 & 0.8 & 0.43 \\
\hline
\end{tabular}

Compare untied and tied grants. The total gain to the recipient is the same in each case (100 clinics worth $\$ 80,000$ each if purchased from the cheapest supplier in the world market, summing to $\$ 8 \mathrm{~m}$ ). But the cost to the taxpayer is $\$ 2 \mathrm{~m}$ higher with tied aid. Tied aid is therefore less efficient than untied grant aid, because a larger taxpayer sacrifice is needed for a given gain to the recipient: the benefit/cost ratio falls from 1 to 0.8 .

Now compare tied grants with the DIFF. The number of clinics under the DIFF alternative $(286=100 / 0.35)$ has been chosen so that the cost to the taxpayer is the same in both cases $(\$ 10 \mathrm{~m})$. But under the DIFF, the gain per clinic is lower, since the recipient has to pay 65 per cent of the Australian purchase price (that is, $\$ 65,000)$. Subtracting this amount from the value of each clinic $(\$ 80,000)$ leaves a gain of only $\$ 15,000$ per clinic, or $\$ 4.3 \mathrm{~m}$ in total. DIFF aid is therefore less efficient than tied grant aid, because a given taxpayer sacrifice results in a smaller gain to the recipient, even though the physical size of the aid project is much greater. The benefit/cost ratio now falls to 0.43 . 
It is not surprising that DIFF exporters should have encouraged support for the idea that the aid budget should be spent on Australian suppliers. It is unlikely, however, that the general public would take into account the possibility that this restriction may result in a diminution of the value of aid to the recipient. As the above example makes clear, every dollar gained by the supplier comes at the expense of the recipient. Thus, the specific arguments in favour of the DIFF - that it helped exporters develop new markets in competition with suppliers who also enjoyed subsidies from their own governments, and that it allowed the leveraging of taxpayers' funds to generate larger, more impressive, aid projects - seem to be little more than convenient rationalisations.

\section{Conclusion}

The commercial-benefit objective of Australian aid conflicts with the desire to deliver development benefits at least cost to the taxpayer. In particular, it is clear that what AusAID chooses to refer to as 'commercial benefits to Australia' should be described as 'commercial benefits to Australian firms, at the expense of taxpayers'. The notion that the DIFF provided something for nothing - a benefit to Australian firms at no cost to Australian taxpayers or recipient governments - is nonsense. The leveraging characteristic of the DIFF, combined with tying, made it less efficient than tied grant aid, which in turn is less efficient than untied grant aid. Even more than the mere tying of aid to Australian suppliers, the DIFF reduced the benefit to recipient governments for a given taxpayer outlay.

By removing the DIFF from Australia's aid program, therefore, the government acted in taxpayers' interests. 'To be consistent, however, it now needs to drop the pretence that the aid program can provide 'commercial benefits' to Australians generally rather than merely transferring funds from taxpayers to Australian exporters of aid projects, and discontinue the practice of tying altogether.

\section{References}

DFAT-AusAID (1996), 'Joint DFAT and AusAID submission on the Development Import Finance Facility', submitted to the Senate Foreign Affairs, Defence and Trade References Committee Inquiry into the Development Import Finance Facility, Canberra.

McCawley, P. (1993). 'Who Benefits from Mixed Credits?', pp. 12-36 in Australian International Development Assistance Bureau, Development with a DIFFerence, Canberra.

Owen, A. (1996), 'Submission to the Senate inquiry into DIFF', submitted to the Senate Foreign Affairs, Defence and Trade Reference Committee Inquiry into the Development Import Finance Facility, Canberra.

Peck, D. (1993), 'The Trade Creation Impact of DIFF - An Exporter's Perspective', pp. 76-85 in Australian International Development Assistance Bureau, Development with a DIFFerence, Canberra.

Rollason, R. (1993), 'The NGO Critique of the Development Import Finance Facility', pp. 7-11 in Australian International Development Assistance Bureau, Development with a DIFFerence, Canberra. 